object of this new radio service is to speed up the transmission of essential traffic messages, meteorological reports, and so on, involved in the operation of the cross-Channel air routes; and on account of its freedom from interference and its immunity from the effect of weather conditions, the service is likely to be highly successful and to add materially to the safety of air-travel between England and France.

\section{Gas Warfare and Civilian Populations}

DR. F. A. FreEtr, of Imperial Chemical Industries, Ltd., addressing a meeting of the City of London Branch of the League of Nations Union on January 26, made some caustic comments on the subject of the position of the civilian population in chemical warfare. The topic of chemical warfare has been so forced on the attention of the populace, he said, that the main danger in case of such an attack would be a psychological one. Every chemical industry necessarily uses various kinds of poisonous materials, gaseous and otherwise, in its processes; but as a menace to the civilian population, they are not worth considering. The really 'killing' gases are of low density and in consequence quickly disperse in the atmosphere. As examples, Dr. Freeth mentioned hydrocyanic acid and carbon monoxide, both of which are particularly subtle poisons. Now the exhaust of an idling motor-bus contains about 6 per cent of carbon monoxide and, in consequence, the atmosphere of a narrow thoroughfare like Bond Street in London must, during a busy time, contain considerable quantities of the gas. Yet owing to the ventilation provided by the air, it is not allowed to accumulate. Of the heavier gases used in warfare, Dr. Freeth mentioned chlorine, which requires for its use a quiet atmosphere and a gentle breeze in the desired direction, and mustard gas, which does not spread rapidly and on wet porous soils decomposes. The percentage of deaths to casualties from mustard gas during the War was less than four. If during a gas raid, a man was able to keep his head sufficiently to shut all the windows of his house and put out the fires, he would be able to wait, in reasonable safety apart from a direct hit, until the authorities had dispersed the gas.

\section{Geography and World Citizenship}

THE Education Committee of the League of Nations Union has been meeting for some years and initiating and advising methods for making international questions and an international spirit a more integral part of ordinary school and college work. It is largely through the activity of this committee that teachers as a profession stand so firmly by the League of Nations. Meetings and conferences are arranged, lecturers sent out and publications of various kinds issued from time to time. Of the latter, a brochure has just appeared (to be obtained from 15, Grosvenor Crescent, S.W.1, price 4d.) on "Geography Teaching in relation to World Citizenship". It is edited by Prof. J. F. Unstead with the help of a number of London teachers of geography and others, and will be approved by all engaged in similar work. The subject has always been regarded in schools as more obviously international than history, and for that reason much of what is said in the pamphlet will appear somewhat commonplace. But there is no objection to enforcing emphatically some of the great commonplaces of human life and thought. It is useful to have set out clearly and in sufficient detail (as here) the main aspect of the inter-relationship of land and people and of the various peoples among themselves throughout the world.

THE attitude of the various contributors to this pamphlet is sane and well-balanced, and they lay stress on those points in their theme which call for most emphasis at the present time. Thus in relation to the mixture of races, it is pointed out that all over Europe-in Germany as well as elsowherethere has been a blending of stocks, a 'give and take' in blood as well as in ideas. But there is no attempt to pass over, or minimise, the reality or value of the contribution to the whole made by the various national units, based on a definite territorial region. The summary, for example, given of a supposed complete answer to the question, 'What should Italy imply to a well-educated person ?', goes from an account of its physiography and natural products to its highest fruit in human genius-Dante, Leonardo, St. Francis, Galileo and the rest. The link is thus brought out between the teaching of geography and history, the more difficult subject. It is understood that a further similar brochure will deal with history.

\section{Lord Derby and the University of Liverpool}

THE completion by Lord Derby of twenty-five years as Chancellor of the University of Liverpool was celebrated on January 26 by a special congregation at which honorary degrees were conferred by the Chancellor upon Lady Derby, Lord Halifax (Chancellor of the University of Oxford) and $\mathrm{Mr}$. Stanley Baldwin (Chancellor of the University of Cambridge). Lord Halifax was unable to attend. Following an address by the Vice-Chancellor (Dr. H. J. W. Hetherington) on the growth of the University and the close associations, so long maintained, between Lord Derby, his immediate predecessors, and the University, the graduans were presented by the Public Orator (Prof. Lyon Blease) for the degree of Doctor of Laws. Following the graduation, Mr. Baldwin addressed the congregation and conveyed the congratulations of the University of Cambridge to the University of Liverpool upon the occasion. As the "newest of Chancellors", Lord Halifax conveyed congratulations in writing to both the University and the Chancellor upon the silver wedding of their partnership. In the evening Lord Derby, Lady Derby, The Earl of Crawford and Balcarres, members of the Derby family and the civic heads of the City of Liverpool and Merseyside were the guests at a dinner given by the University Association.

\section{Indian Earthquake of January 15}

THe India Office has issued a general survey of the effects of the earthquake. The number of lives lost would appear to be in the neighbourhood of six thousand. The destruction of houses is greatest in the 
towns of North Bihar and Monghyr, especially Darbhanga, Muzaffarpur and Motihari. Outside the towns, the principal effects are broken and obliterated roads, the collapse of bridges, floods and great fissures in the ground, from which mud, sand and water have issued, covering fields and crops with a devastating slimy deposit. The central area contains more than 300 square miles under sugar-cane. Though much of this has been saved, nearly all the sugar-mills have been destroyed. The chief difficulties at present are the supply of drinking water and the prevention of epidemics in towns and villages.

\section{Palestinian Remains at the British Museum}

THE next special exhibition of prehistoric material at the British Museum will be opened on February 5 and will remain open for two or three months. Two cases at the head of the main staircase, in the Department of British and Medirval Antiquities, will be devoted to a display of a typical series from stratified caves near Mount Carmel, where excavations have been carried out by the British School of Archæology in Jerusalem and the American School of Prehistoric Research, with Miss D. A. E. Garrod as field-director. Skeletal remains of palæolithic man will be shown (Palceanthropus palestinensis), and a sequence of implements from an early phase of the Palæolithic to Mesolithic, the latter being known as Natufian. A special feature of the excavations is the blend of St. Acheul and Le Moustier elements for a period; and a long succession of Aurignac types gives place to the post-palæolithic with a different and peculiar fauna. The abundant yield is incidentally useful for its similarities and contrasts to the better-known European industries, and special interest is attached to the beginnings of agriculture in Palestine.

\section{Velocity of Light}

As was to be expected, the announcement which appeared in the press last summer (NATURE, 130, 25, July 2; 277, Aug. 20, 1932) to the effect that the latest experiments indicated a periodic variation in the velocity of light, has been construed in the sense that some seasonal instrumental error was at work. Science Service now issues an official confirmation of this view, given by the Mount Wilson authorities. The report adds that the best value for the velocity of light is now $299,774 \mathrm{~km}$. $/ \mathrm{sec}$. and that further analysis is only likely to change the last figure by one or two units. The present investigation of the velocity of light is being carried out by Pease and Pearson, who are continuing Michelson's work and using the well-known rotating mirror method. It will be remembered that when Michelson used long base lines between mountain peaks, he found that irregularities in atmospheric refraction-the astronomer's "bad seeing"-interfered with the definition of the reflected image. The base is now in vacuo, in a pipe line a mile in length. To obtain more accurate results, it would be necessary to build a more stable pipe line, use quartz mirrors and employ elaborate timing devices.

\section{Projected Electric Railways in Pälestine}

IN the Electrician of January 5 a description is given of a projected railway system for Palestine radiating from Jerusalem. Four new lines will radiate from a terminus at Jerusalem located outside the city on the northern side and east of the Damascus Gate. Possibly recent economic developments in the country, the most important of which is the new harbour at Haifa on the Mediterranean, has tended to emphasise the isolated position of Jerusalem so far as railway facilities are concerned. The northern line is to be 67 miles long, starting from the Jerusalem terminus, going through the Jordan valley, where the line descends to 500 feet below the Mediterranean level, finally getting to Tul Keram Junction on the main Haifa-Cairo line. The eastern line (55 miles) would run from the terminus, crossing the River Jordan, passing through the Kalaat ez Zerka Station on the Hejaz railway to Ammam, the capital of Transjordan and the headquarters of the British Government's High Commissioner. The southern railway (50 miles) would run through Hebron to Beersheba. Finally, there would be a line (18 miles) from Wadi Fara on the northern line through Jericho to the potash works on the shore of the Dead Sea. It is proposed to build a power station and a reservoir in Transjordan and another on the eastern shore of the Dead Sea to provide the electric current for operating the four railways. The latter station would be necessary if an extension railway to the Red Sea should materialise. Some years ago this project was discussed, the terminals of the line being Haifa and the ancient port of Akaba on the Red Sea. This would place Jerusalem on a direct sea-tosea railway from the Mediterranean to the Red Sea. Possibly it might revive the ancient and prosperous traffic route from the Red Sea to the Levant of the times of Solomon and the Romans.

\section{Transmission of Power by High Tension Direct Current}

AT the second World Power Conference held at Berlin in 1930, much consideration was given to international schemes for transmitting large amounts of power by high tension direct current. The most ambitious of these schemes was to transmit one million kilowatts from the western fiords of Norway at a pressure of 500 kilovolts across Sweden and Denmark to the industrial regions in Westphalia, Germany. The great advantage of utilising power from the western fiords is that a uniform output of power all the year round could be obtained. It was proposed that the line should pass through Göteborg and Copenhagen to Hamburg, small amounts of power being tapped off at the two former cities, but the great bulk being delivered to Hamburg for distribution in the German networks. In a paper read to the Institution of Electrical Engineers on January 18, H. Rissik discussed the engineering aspects of the problem. He pointed out that with the same overhead lines, much larger currents can be used with direct than with alternating currents and the difficulties of working are much less with the former than with the latter. On the other hand, 